\title{
Nutritional Status of Children in the Aspirational Districts of Odisha, India
}

\author{
Anil Kumar*, J. C. Jeeva, A. Sarkar, B. Sahoo and S. K. Srivastava \\ ICAR-Central Institute for Women in Agriculture, Bhubaneswar -751 003, India \\ *Corresponding author
}

\begin{tabular}{|l|}
\hline K e y w o r d s \\
Aspirational \\
districts, Nutritional \\
status, Stunting, \\
Wasting, \\
Underweight, \\
Odisha
\end{tabular}

Aspirational districts programme was launched by the government of India in 2017 to raise the living standards of people in 115 backward districts of the country by focusing on five key sectors which included among others health and nutrition. Nutritional status of children and socio-economic status in the ten aspirational district of Odisha were studied. Children in the aspirational districts were undernourished in all the three indicators: stunting, wasting and underweight as compared to the state average. The highest stunting (in percent) was prevalent in Nabarangapur (45.8) followed by Malkangiri (45.7), Balangir (44.4), Raygada (43.5) and Koraput (40.3). Nabarangapur (36.0 percent), Malkangiri (32.5 per cent), Korput (28.5), Balangir (26.1) and Kalahandi (24.8) had higher prevalence of 'wasting' children. Malkangiri district and Nabarangapur had over 50 percent underweight children and in five other districts (Balangir, Koraput, Kandhamal, Raygada and Nuapada) over 40 percent of children were underweight. The aspirational districts in Odisha are tribal dominated with lower literacy levels and a much higher gender gap in literacy and there is an urgent need for targeted approach by implementing the ICDS programme, Mid-day meal scheme etc. to address the incidence of child malnourishment.

\section{Introduction}

There has been rapid economic development in India over the last few decades after opening of the economy. Still it is home to the largest number of poor people. According to a recent World Bank report (2018), half of the world's 736 million extreme poor in 2015 i.e. 368 million live in just five countries namely, India, Nigeria, DR Congo, Ethiopia and Bangladesh. In India alone, there were 175.7 million persons living under extreme poverty (those living on less than Rs135.0 a day) with a poverty rate of 17.7 percent. Therefore, to achieve the global target of reducing extreme poverty to less than 3 percent by 2030, a focussed attention is required especially in India. For all people to share the benefits of economic development equally, several efforts have been made to identify the pockets of underdevelopment and make plans to bring them to the national mainstream. The latest in 
this effort was initiated by the government of India in 2017 by identifying 115 aspirational districts. Of the 115 aspirational districts, Niti Aayog identified 30 most backward districts on the basis of a composite index which used the datasets from SECC Deprivation, Nutrition and health data (NFHS-4), Elementary education data and data pertaining to households without electrifications, without access to drinking water and toilets and unconnected villages. In addition to these 30 districts, different Ministries identified a pool of 50 districts on the basis of this index where they wanted to converge their efforts for improvement in the outcome. Besides these, 35 districts with prevalence of Left-Wing Extremism (LWE) were also selected as backward districts. To raise the living standards of its citizens and ensuring inclusive growth for all, the progress of the 115 aspirational districts is measured by 49 key performance indicators (81 data-points) from the 5 identified thematic areas, chosen after several rounds of consultations with various stakeholders. The aspirational district programme focuses closely on improving people's ability to participate fully in the vibrant economy particularly focussing on Health \& Nutrition, Education, Agriculture \& Water Resources, Financial Inclusion \& Skill Development, and Basic Infrastructure.

In Odisha there are 30 districts, of which ten districts namely, Dhenkanal, Gajapati, Kandhamal, Balangir, Kalahandi, Rayagada, Koraput, Malkangiri, Nuapada and Nabarangpur have been identified as the aspirational districts. The ten aspirational districts have 101 blocks for which detailed socio-economic indicators including status of women in agriculture have been analyzed. The programme also aimed to prepare a District Action Plan for each identified district spelling out the blue print for achieving the targets for various indicators to be achieved year wise upto 2022. Therefore, the present study was taken up to analyse the key socio-economic indicators in the aspirational districts so that focussed attention can be made to achieve the targets.

\section{Materials and Methods}

The data for this study was taken from Census of India (Census 2011) on the aspects of socio-economic indicators which included population characteristics, scheduled caste and scheduled tribe population, literacy, etc. and analysed for the aspirational districts and compared with the state average. Similarly, the data on nutritional status respect to stunting, wasting and underweight of children were taken from NFHS-4 (2018). The data on nutritional status is available as percent for the district as whole, for urban and for rural areas. Therefore, for calculating the average nutritional status in the aspirational districts, the percent data for indicators for each district was multiplied with the population of children, and added for all the aspirational districts and thereafter percent value for each indicator were calculated for the aspirational district as a whole.

Mapping the aspirational districts: GIS map was created for the socio-economic and nutritional indicators for the ten aspirational districts of Odisha using the open source software QGIS 3.43. The various indicators were then projected in the map for easy comprehension and analysis. In the present study, the terminology 'aspirational' and 'backward' have been used inter-changeably and conveys the same meaning as the districts identified in the 'Aspirational districts' programme of the Government of India

\section{Results and Discussion}

Health and nutrition outcome are important for the wellbeing of a population which has found the highest importance in the indicators 
identified for measuring the progress of aspirational districts by the Niti Aayog. Health $\&$ nutrition and education sector both have been given 30 percent weight each for comparing the aspirational districts. The other sectors identified by the Niti Aayog are: agriculture \& water resources (20 percent), financial inclusion (5 percent), skill development (5 percent) and basic infrastructure (10 percent).

The aspirational districts in Odisha are mostly located in the southern part (Fig. 1) except Dhekanal. Seven districts (Balangir, Nuapada, Kalahandi, Nabarangpur, Rayagada, Koraput and Malkangiri) identified as the aspirational districts formed part of the erstwhile KBK (Kalahandi, Balangir, Koraput) districts has traditionally lagged behind in the development parameters and therefore special plan has been initiated by the government to bring these districts at par with other regions.

The aspirational districts are spread over an area of 62.1 thousand sq $\mathrm{km}(39.9 \%$ of the State). The aspirational districts together had a total population of 10.52 million $(25.1 \%$ of Odisha) of which the rural population was $9.40 \mathrm{~m}$ (26.9\% of rural population of Odisha). There were $2.26 \mathrm{~m}(28.0 \%$ of state $)$ households in the rural areas of the aspirational districts. In terms of geographical area, Koraput (8.8 th sq $\mathrm{km}$ ) is the largest among aspirational districts and the smallest district is Nuapada (3.85th sq km). Balangir district has the highest population $(1.65 \mathrm{~m})$ and the lowest population is in Gajapati $(0.58$ $\mathrm{m})$.

The population density (person per sq $\mathrm{km}$ ) in the aspirational districts was 169 which is lower than the state average (270) (Table 1). The population density in Dhenkanal (268) was at par with the state average and in other districts it ranged between 91 (Kandhamal) to 251 (Balangir). The sex ratio in all the districts except Dhenkanal and Balangir was more than 1000 and it was highest in Raygada (1051). Again, seven of the ten districts have more than 50 percent scheduled tribe population. The literacy rate in the aspirational districts was only 58.1 per cent against the state average of 72.9 per cent. Female literacy also lagged behind the state average being only 47.1 per cent against the state average of 64.0 per cent. Four districts (Raygada, Koraput, Malkangiri and Nabarangapur) had female literacy below 40 percent. The gender gap in literacy in the aspirational districts was 22.2 per cent against the state average of 17.6 per cent. Kandhamal, Kalahandi and Nuapada districts had over 25 per cent gender gap in literacy.

\section{Nutritional status of children}

There is an intricate linkage between agriculture and nutrition which is manifested through various pathways which include access to food, securing income, demand-andsupply determining food prices (affordability), empowerment of women in agriculture and women's health determining their participation in agricultural activities. Of late, the government has initiated programmes supporting nutrition-sensitive agriculture for achieving the developmental goals. Nutritional status of children is an important indicator which tells about the access to food. The nutritional status of children is measured as stunted, wasted and underweight. Table 2 gives the per cent of children in the category of stunted, wasted and underweight in the ten aspirational districts of Odisha. Children in the aspirational districts are undernourished in all the three indicators as compared to the state average. The highest stunting (in percent) was prevalent in Nabarangapur (45.8) followed by Malkangiri (45.7), Balangir (44.4), Raygada (43.5) and Koraput (40.3) and the lowest was in Dhenkanal (26.1) as against the state average of 34.4 percent. 
Table.1 Socio-economic indicators in the aspirational districts of Odisha (2011)

\begin{tabular}{|c|c|c|c|c|c|c|c|c|c|}
\hline District & $\begin{array}{c}\text { Rural } \\
\text { populat } \\
\text { ion \% }\end{array}$ & $\begin{array}{c}\text { Human } \\
\text { density } \\
(\text { no/sq } \\
\text { km) }\end{array}$ & $\begin{array}{c}\text { Sex } \\
\text { ratio }\end{array}$ & $\begin{array}{c}\text { Schedu } \\
\text { led } \\
\text { tribe } \%\end{array}$ & $\begin{array}{c}\text { Schedu } \\
\text { led } \\
\text { caste } \\
\%\end{array}$ & $\begin{array}{c}\text { Total } \\
\text { literacy } \\
(\%)\end{array}$ & $\begin{array}{c}\text { Male } \\
\text { literacy } \\
(\%)\end{array}$ & $\begin{array}{c}\text { Female } \\
\text { literacy } \\
(\%)\end{array}$ & $\begin{array}{c}\text { Gender } \\
\text { gap in } \\
\text { literacy } \\
(\%)\end{array}$ \\
\hline Balangir & 88 & 251 & 987 & 21.1 & 17.9 & 64.7 & 75.8 & 53.5 & 22.3 \\
\hline Dhenkanal & 90.1 & 268 & 947 & 13.6 & 19.6 & 78.8 & 86.2 & 71 & 15.2 \\
\hline Gajapati & 87.8 & 134 & 1043 & 54.3 & 6.8 & 53.5 & 64.4 & 43.2 & 21.2 \\
\hline Kalahandi & 92.3 & 199 & 1003 & 28.5 & 18.2 & 59.2 & 71.9 & 46.7 & 25.2 \\
\hline Kandhamal & 90.1 & 91 & 1037 & 53.6 & 15.8 & 64.1 & 76.9 & 51.9 & 25 \\
\hline Koraput & 83.6 & 157 & 1032 & 50.6 & 14.2 & 49.2 & 60.3 & 38.6 & 21.8 \\
\hline Malkangiri & 91.9 & 106 & 1020 & 57.8 & 22.6 & 48.5 & 59.1 & 38.3 & 20.8 \\
\hline $\begin{array}{c}\text { Nabaranga } \\
\text { pur }\end{array}$ & 92.8 & 231 & 1019 & 55.8 & 14.5 & 46.4 & 57.3 & 35.8 & 21.5 \\
\hline Nuapada & 94.4 & 158 & 1021 & 33.8 & 13.5 & 57.3 & 70.3 & 44.8 & 25.5 \\
\hline Rayagada & 84.8 & 137 & 1051 & 56 & 14.4 & 49.8 & 61 & 39.2 & 21.9 \\
\hline $\begin{array}{l}\text { Aspirationa } \\
\text { I districts }\end{array}$ & 89.3 & 169 & 1010 & 39.4 & 16.2 & 58.1 & 69.3 & 47.1 & 22.2 \\
\hline Odisha & 83.3 & 270 & 979 & 22.8 & 17.1 & 72.9 & 81.6 & 64 & 17.6 \\
\hline
\end{tabular}

Table.2 Nutritional status of children in the aspirational districts of Odisha - overall and in rural areas

\begin{tabular}{|c|c|c|c|c|c|c|c|}
\hline & \multicolumn{3}{|c|}{ Overall } & \multicolumn{3}{c|}{ Rural areas } \\
\hline District & $\begin{array}{c}\text { Stunted } \\
\text { (height- } \\
\text { for- } \\
\text { age): } \\
\text { HAZ }\end{array}$ & $\begin{array}{c}\text { Wasted } \\
\text { (weight-for- } \\
\text { height): } \\
\text { WHZ }\end{array}$ & $\begin{array}{c}\text { Underweig } \\
\text { ht (weight- } \\
\text { for-age): } \\
\text { WAZ }\end{array}$ & $\begin{array}{c}\text { Stunted } \\
\text { (height- } \\
\text { for- } \\
\text { age): } \\
\text { HAZ }\end{array}$ & $\begin{array}{c}\text { Wasted } \\
\text { (weight-for- } \\
\text { height): } \\
\text { WHZ }\end{array}$ & $\begin{array}{c}\text { Underwei } \\
\text { ght } \\
\text { (weight- } \\
\text { for-age): } \\
\text { WAZ }\end{array}$ \\
\hline Balangir & 44.4 & 26.1 & 44.7 & 44.4 & 28.3 & 46.8 \\
\hline Dhenkanal & 26.1 & 19 & 29.2 & 28.7 & 18.6 & 31.2 \\
\hline Gajapati & 32.5 & 18.4 & 32.1 & 34 & 18.9 & 33.9 \\
\hline Kalahandi & 36.6 & 24.8 & 39.7 & 37.3 & 25.5 & 40.8 \\
\hline Kandhamal & 38.4 & 23.1 & 43.1 & 39.5 & 23.5 & 44.3 \\
\hline Koraput & 40.3 & 28.5 & 44.4 & 43.7 & 29.3 & 46.3 \\
\hline Malkangiri & 45.7 & 32.5 & 51.8 & 47.2 & 33 & 52.5 \\
\hline Nabaranga & 45.8 & 36 & 51 & 46.6 & 36 & 51.6 \\
\hline pur & & & & & & & \\
\hline Nuapada & 37.6 & 26.4 & 40 & & 36.4 & 27 & 40 \\
\hline Rayagada & 43.5 & 23.1 & 42.4 & & 46.5 & 23.3 & 44.4 \\
\hline $\begin{array}{c}\text { Aspirationa } \\
\text { l districts }\end{array}$ & 39.8 & 26.5 & 42.6 & & 41.2 & 27.2 & 44.0 \\
\hline Odisha & $\mathbf{3 4 . 4}$ & $\mathbf{2 0 . 5}$ & $\mathbf{3 4 . 7}$ & $\mathbf{3 5 . 6}$ & $\mathbf{2 1 . 1}$ & $\mathbf{3 6 . 1}$ \\
\hline
\end{tabular}


Fig.1 Aspirational districts of Odisha with blocks

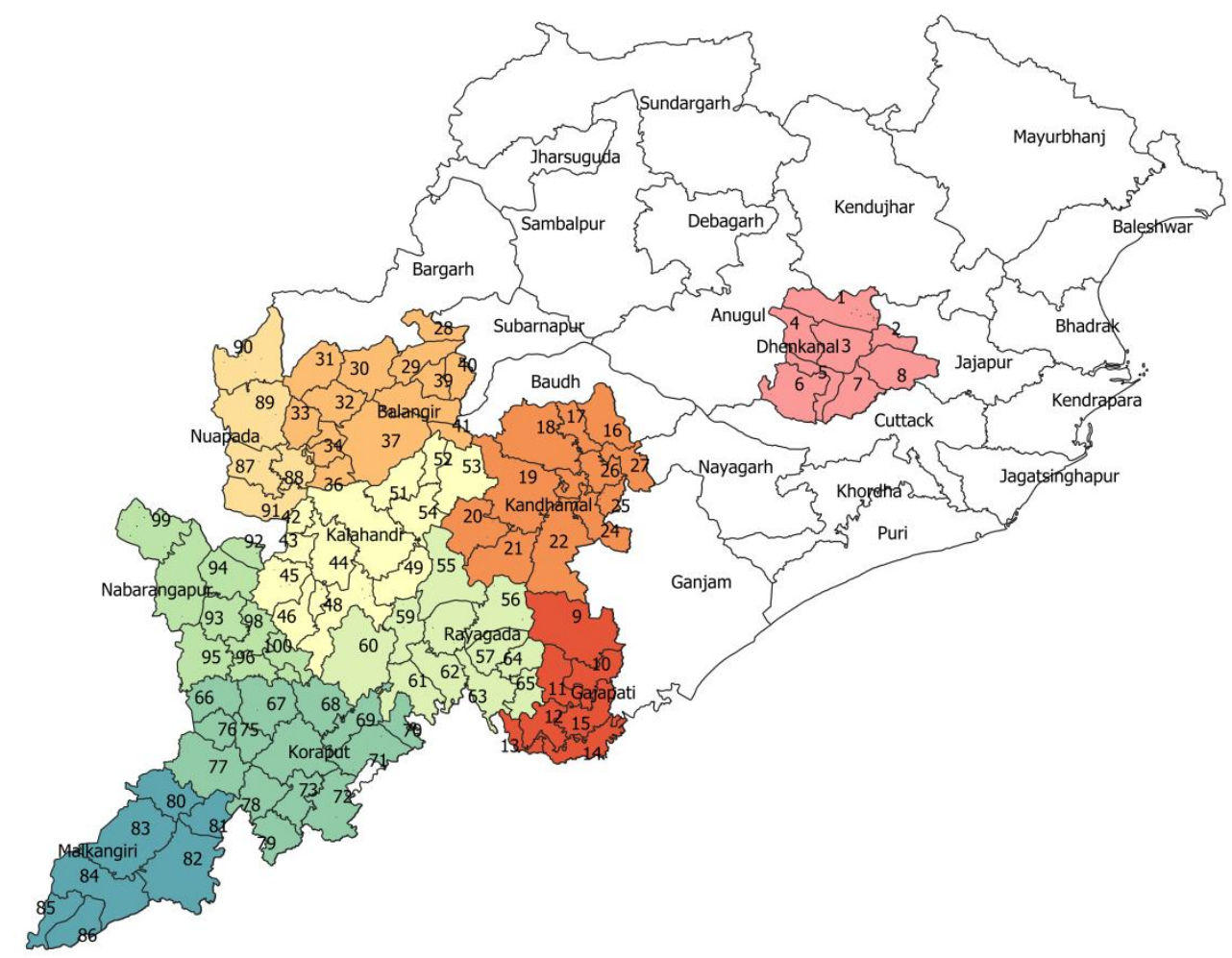

Similarly, in the aspirational districts, there were 26.5 percent children who were in the category of 'wasted' i.e. they had lower weight relative to height as compared to the state average of 20.5 percent. Nabarangapur (36.0 percent), Malkangiri (32.5 per cent), Korput (28.5), Balangir (26.1) and Kalahandi (24.8) were the districts with higher prevalence of 'wasting' children. Malkangiri district and Nabarangapur had over 50 percent underweight children and in five other districts (Balangir, Koraput, Kandhamal, Raygada and Nuapada) over 40 percent of children were undernourished. In aspirational districts as a whole, there were 41.6 percent underweight children as compared to the state average of 34.7 percent. In rural areas, the prevalence of stunted, wasted and underweight children were more than the average of the district. The state government is implementing the ICDS programme for children of 0 to 6 years age to provide i) immunization, ii) health check-up, iii) supplementary nutrition, iv) referral services, v) pre-school education, and vi) health \& nutrition education (Govt. of Odisha, 2018). Besides, Mid-Day Meal Scheme is being implemented by the School \& Mass Education Department to provide wholesome meal to school children from standard I to VIII. Status of women in the society and their education have important bearing on the household nutrition.

Also the agricultural development has a close linkage with the health and well being of women which in turn affects the household nutrition. Therefore, a concerted effort is required to address the problem of child malnutrition addressing both the direct as well the indirect factors accounting for it. Uniform 
development of all regions of the country is an important goal of the government which prompted it to initiate the aspirational districts programme with an aim to give priority attention to the sectors related to agriculture, infrastructure and human development. To raise the living standards of people in these aspirational districts, the programme aimed to focus five key sectors which included i) Health \& Nutrition, ii) Education, iii) Agriculture \& Water Resources, iv) Financial Inclusion \& Skill Development, and v) Basic Infrastructure. The study indicated that the aspirational districts in Odisha are tribal dominated with lower literacy levels and a much higher gender gap in literacy. These districts have one of the lowest female literacy rates in India which in turn is reflected in the nutritional status of children and the overall wellbeing of the population. Therefore, there is need for targeted approach for its redressal to bring these aspirational districts on par with the mainstream India.

\section{References}

Census of India. 2011. Census data. Retrieved from http://censusindia.gov.in.

Govt. of Odisha. 2018. Outcome Budget 2017-18. Department of Women \& Child Development and Mission Shakti. Government of Odisha.

NFHS-4. 2018. National Family Health Survey-4. http://rchiips.org/nfhs/districtfactsheet NFHS-4.shtml

NFSM. 2018. National Food Security Mission. https://www.nfsm.gov.in/nfmis/statepr ofile/state.aspx

NITI Aayog. 2018. The Aspirational Districts Dashboard. http://championsofchange.gov.in

World Bank. 2018. Poverty and Shared Prosperity 2018: Piecing Together the Poverty Puzzle. Washington, DC. www.worldbank.org

\section{How to cite this article:}

Anil Kumar, J. C. Jeeva, A. Sarkar, B. Sahoo and Srivastava, S. K. 2019. Nutritional Status of Children in the Aspirational Districts of Odisha. Int.J.Curr.Microbiol.App.Sci. 8(12): 19101915. doi: https://doi.org/10.20546/ijcmas.2019.812.228 